\section{World Birth Defects Day — March 3, 2016}

The importance of World Birth Defects Day on March 3 is underscored as the world's attention has turned to the Zika virus, and scientists around the world are investigating the possible association between Zika virus infection and microcephaly.

Every year, an estimated 3\%-6\% of infants worldwide are born with a serious birth defect $(1,2)$. Birth defects can affect an infant regardless of birthplace, race, or ethnicity. In some countries, birth defects remain one of the leading causes of death for infants and young children (3). Those who survive and live with these conditions are at an increased risk for lifelong disabilities.

To raise global awareness about birth defects, 34 countries on five continents joined together to support World Birth Defects Day in 2015, its inaugural year (4). On March 3, 2015, the social media presence of the hashtag \#WorldBDDay reached nearly 3.4 million persons around the world.

For World Birth Defects Day 2016, the same group of partners has reconvened and invited others to join them, to continue to bring attention to this global public health issue.
The goals for 2016 are to raise awareness about birth defects, reduce stigma, and increase opportunities for prevention by promoting the following: 1 ) increasing the number of birth defects surveillance programs globally, 2) improving existing birth defects surveillance programs, 3) improving access to care, and 4) continuing research on the causes of birth defects.

CDC invites other organizations around the world to participate in World Birth Defects Day 2016 by sharing stories and information about birth defects using the hashtag \#WorldBDDay.

\section{References}

1. CDC. Update on overall prevalence of major birth defects-Atlanta, Georgia, 1978-2005. MMWR Morb Mortal Wkly Rep 2008;57:1-5.

2. Christianson A, Howson CP, Modell B. March of Dimes: global report on birth defects. The hidden toll of dying and disabled children. White Plains, NY: March of Dimes Birth Defects Foundation; 2006. http:// www.marchofdimes.org/materials/global-report-on-birth-defects-thehidden-toll-of-dying-and-disabled-children-full-report.pdf

3. World Health Organization. Congenital anomalies. Geneva, Switzerland: World Health Organization; 2015. http://www.who.int/mediacentre/ factsheets/fs370

4. International Clearinghouse for Birth Defects. World Birth Defects Day report summary. Rome, Italy: International Clearinghouse for Birth Defects; 2015. http://icbd.org/WBDD/WBDD_Report_Summary.pdf 